\title{
MOOCs in STEM Education: Teacher Preparation and Views
}

\author{
Bekir Yıldırım ${ }^{1}$ (D)
}

Accepted: 17 October 2020 / Published online: 27 October 2020

(c) Springer Nature B.V. 2020

\begin{abstract}
This study investigated teachers' views of Massive Open Online Courses (MOOCs). The sample consisted of 30 teachers recruited from different cities of Turkey using criteria sampling. Phenomenology was the research method of choice. Data were collected using a semi-structured interview form and analyzed using content analysis. Participants use MOOCs because they are free of charge and have good content and high quality. MOOCs help them learn science, technology, engineering, and mathematics, gain professional knowledge, and develop skills, and positive attitudes and values. Most participants are interested in integrating MOOCs in their classes; however, they face various problems during MOOCs, such as loss of motivation and Internet connection issues. It is recommended that MOOCs be designed in such a way that they increase participants' motivation and allow for feedback.
\end{abstract}

Keywords MOOC $\cdot$ Teacher $\cdot$ Teacher preparation $\cdot$ Views

\section{Introduction}

Advances in information and communication technology (ICT) have transformed not only various fields of knowledge (from health to law) but also how we perceive education. This change has led to a revision of higher education and promoted the efforts to integrate ICTs in higher education (Turan et al. 2013). Recent developments of ICT provide flexibility and facilitate access to information, leading to the emergence of online higher education platforms, one of which is massive open online courses (MOOCs).

\section{Massive Open Online Courses}

Massive Open Online Courses are free and easily accessible courses that allow thousands of people to receive education at the same time. MOOCs were inspired by the Connectivism and Connective Knowledge course developed by Downes and Siemens in 2008

Bekir Yıldırım

bekir58bekir@gmail.com

1 Department of Mathematics and Science Education, Faculty of Education, Mus Alparslan University, Mus 49250, Turkey 
(Cormier and Siemens 2010). Massive Open Online Courses have attracted widespread interest in the last decade, but they have been offering courses and certificates on such websites as Coursera, edX, and Udemy since 2012 (Baggaley 2013). Today, MOOCs are also used as a new version of e-learning in higher education and professional development programs (Conole 2014; Laurillard 2016; Vivian et al. 2014; Wang et al. 2018). Massive Open Online Courses have been a point of controversy since they became part of higher education and professional development programs. For example, Martin (2012) and Miller (2012) argue that MOOCs are a disruptive innovation for higher education, whereas Lederman (2013) states that they result in less learning than face-to-face education. Besides, only about $25 \%$ of those who enroll in MOOCs complete the courses, which is one of the major setbacks (Bozna 2016; Castaño-Muñoz et al. 2018; Jordan 2014; Radoiu 2014). Another setback is the inadequate technological infrastructure of MOOCs (Sukhbaatar et al. 2018). However, MOOCs are becoming more and more popular and are increasingly used in higher education because they are free of charge, have open resources, promote student-student interaction and contextual learning, and break the limits of time and space.

Massive Open Online Courses have two models (Conole 2013; Daniel 2012); cMOOCs and xMOOCs. cMOOCs place heavy emphasis on knowledge production in network learning environments, while xMOOCs concentrate on repetition and presentation (Conole 2013; Daniel 2012). Coursera, edX, and Udemy are the most popular xMOOCs platforms that offer courses on different topics. xMOOCs are used in a wide range of areas, especially computer engineering, philosophy, history, and nursing (Bellack 2013; Sharma et al. 2014). It has, however, not been long since MOOCs were integrated into professional development programs for teachers (Kellogg and Edelmann 2015; Koutsodimou and Jimoyiannis 2015; Laurillard 2016). Teachers can attend online courses out of work whenever and wherever they want. Therefore, MOOCs are used as an alternative to conventional teacher training programs (Koukis and Jimoyiannis 2018).

Although MOOCs are gaining popularity all over the world, their impact has been understudied (Koukis and Jimoyiannis 2018; Karlsson et al. 2014; Koukis and Jimoyiannis 2017; Koutsodimou and Jimoyiannis 2015; Spradling et al. 2015). Besides, those studies address such topics as coding and the use of web-based tools in language teaching. However, few MOOCs concentrate on the fields of science, technology, engineering, and mathematics (STEM). The "STEM 2026" by the American Institutes for Research (2015) states that MOOCs can be used for STEM education. Subbian (2013) also argues that MOOCs can be used to facilitate interdisciplinary education by teaching STEM fields.

\section{STEM Education}

STEM education is an interdisciplinary approach to learning that integrates the four disciplines of science, technology, engineering, and mathematics and has long been used in numerous countries (the USA, the UK, Canada, etc.) (Sahin 2015). Those countries apply STEM education to achieve economic and technological advances, to establish a link between schools and industries, and to increase science and mathematics literacy (Türk et al. 2018). Moreover, STEM education helps students develop the creativity, problemsolving, and critical thinking skills required by the 21 st-century business world. Therefore, countries integrate STEM education into formal and informal education. Teachers play an essential role in this process (Yıldırım 2020a), but only those who have a good grasp of STEM education can integrate it into formal and informal education (Yildırım and 
Şahin-Topalcengiz 2019). Although STEM education is new to Turkey, many teachers are interested in learning it, increasing the demand for related courses. However, there are few people in Turkey with a Ph.D. in STEM education, and only a certain number of people are allowed to enroll in STEM courses, resulting in unmet demand (Colakoglu and Gokben 2017).

Moreover, STEM courses are too expensive and too short for teachers. Research shows that a teacher ideally needs $80 \mathrm{~h}$ of training to achieve professional development (Johnson and Fargo 2010; Supovitz and Turner 2000). Moreover, teachers are unable to attend longterm courses in STEM education because they take place during the semester, pointing to the need for free and open online STEM courses offered by experts.

\section{The Purpose and Significance of the Study}

Teachers should be provided with free-of-charge and always-accessible online STEM education courses offered by experts. Not all teachers can have training in STEM education, due to different working conditions and socioeconomic status. However, they all can access online STEM courses and attend them whenever and wherever they want. Massive Open Online Courses can, therefore, be used for online STEM education. Teachers can also take them to improve themselves during the Covid-19 pandemic that has taken hold of the whole world. To that end, an 80-h free training on STEM education was designed for participants in line with the STEM Teacher Institutes model (Yıldırım 2020b). The training was based on XMOOCs, allowing attendees to receive direct information about STEM fields. This study is important because it is the first to offer long and free xMOOC training on STEM fields to teachers in Turkey. Moreover, teachers are expected to acquire professional knowledge and develop professional skills and attitudes in STEM education. We, therefore, believe that this study will pave the way for further research on this topic. In this context, this study aimed to determine how teachers perceived MOOCs for STEM education. The main research question was, "What are teachers' views of MOOCs for STEM education?" To this end, the study sought answers to the following subquestions:

1. How do teachers define MOOCs?

2. Why do teachers use MOOCs?

3. What do teachers think are the benefits of MOOCs?

4. What effects do teachers think MOOCs have on professional competence?

5. In what way do teachers think they can use MOOCs in their classes?

6. What problems do teachers face during MOOCs?

\section{Methodology}

Phenomenology, which is a qualitative research method, was used to determine the effects of MOOCs in STEM education. Phenomenology is used to determine how people experience and make sense of a phenomenon or an event (Yıldırım and Şimşek 2011). This was a phenomenological study because it aimed to determine how participants perceived MOOCs and what meaning they attributed to them. 
Table 1 FSEMOOCS Items

1. Why do you use MOOCs?

2. In what way do you think MOOCs help improve professional competence?

Table 2 Inclusion criteria and frequency distribution

\begin{tabular}{llc}
\hline Theme & Codes & Frequency \\
\hline Criteria & Watching all course videos and course introduction videos & 177 \\
& Completing all assignments in STEM-PDT-MOOCs & 115 \\
& Participating in the discussion form in STEM-PDT-MOOCs every week & 87 \\
& Completing STEM-PDT- MOOCs & 87 \\
& Agreeing to be interviewed & 30 \\
\hline
\end{tabular}

\section{Participants}

Participants were recruited using criteria sampling, which involves the selection of a sample that meets a predetermined set of criteria (Y1ldırım and Şimşek 2011). Criteria sampling is a time- and cost-efficient method by which researchers select participants most suited to the research purpose (Patton 2002). Three hundred and ninety-five teachers were enrolled in MOOCs (STEM-PDT-MOOCS) designed for the professional development program for teachers (PDT) in STEM education. Those who met the specified criteria were included in the sample. Table 1

Table 2 shows the sampling procedure. Among 395 participants, 177 watched all the course videos and course introduction videos. Of the 177 participants, 115 completed all assignments. Of the 115 participants, 87 both participated in the discussion form and completed the training successfully. Of the 87 participants, only 30 expressed their views of the process. The sample consisted of 30 teachers from different cities of Turkey who met the inclusion criteria. Participants were assigned pseudonyms (Ali, Ayşe, Mehmet, etc.) in order to assure anonymity. Table 2 shows the participants' demographic characteristics.

\section{Instruments}

\subsection{FSEMOOCS}

Semi-structured interviews were conducted to determine participants' views. A Form for Massive Open Online Courses in STEM Education (FSEMOOCs) was developed for interviews. The purpose of the semi-structured interview form is to help the researcher to control the course of the interview (Merriam 2009). It was made sure that the FSEMOOCs items were easy to understand, open-ended, and allowed for follow-up questions. The FSEMOOCS consisted of six items. It was sent to two experts (one in STEM education, and the other in information technology). The FSEMOOCS was revised based on their feedback. A pilot study was conducted with two teachers to determine the intelligibility of the 
FSEMOOCs, which was then finalized based on the results. Table1 shows two of the FSEMOOCs items. "Appendix" shows all FSEMOOCS items. Table 3

\section{Data Analysis}

Qualitative data were collected through face-to-face interviews. Each interview lasted 10-30 min and was recorded. The interviews were transcribed and then analyzed using content analysis. First, codes were developed from the transcripts by the researcher and an expert. Content analysis was performed by two people to ensure validity and reliability. The parts on which the researcher and the expert agreed and disagreed during coding were identified. They discussed the codes on which they disagreed and reached a consensus. Second, a literature review was conducted to develop categories and themes and to assign the codes to them. Table 4 shows the themes and some of the codes. Table 4 presents explanations for the themes and some codes to allow readers to understand them better.

\section{Procedure}

This six-month study consisted of eight stages: (1) deciding to conduct the study, (2) choosing the best research method, (3) determining the content, (4) implementing the STEM-PDTMOOCs process, (5) completing the training, (6) conducting interviews, (7) analyzing and

Table 3 Participants' demographic characteristics

\begin{tabular}{lll}
\hline Theme & Codes & $\mathrm{f}$ \\
\hline Major & Science & 7 \\
& Classroom Teaching & 6 \\
& Pre-school Teaching & 5 \\
& Mathematics Teaching & 6 \\
& ICT Teaching & 6 \\
& Total & 30 \\
& $1-5$ & 10 \\
Experience (year) & $6-10$ & 9 \\
& $11-15$ & 7 \\
& $\geq 16$ & 4 \\
& Total & 30 \\
Education level (Degree) & Bachelor's & 14 \\
& Master's & 12 \\
& PhD & 4 \\
& Total & 30 \\
Gender & Woman & 18 \\
& Man & 12 \\
& Total & 30 \\
\hline
\end{tabular}

Participants had different majors and durations of experience. Most participants were women and had a bachelor's or master's degree 


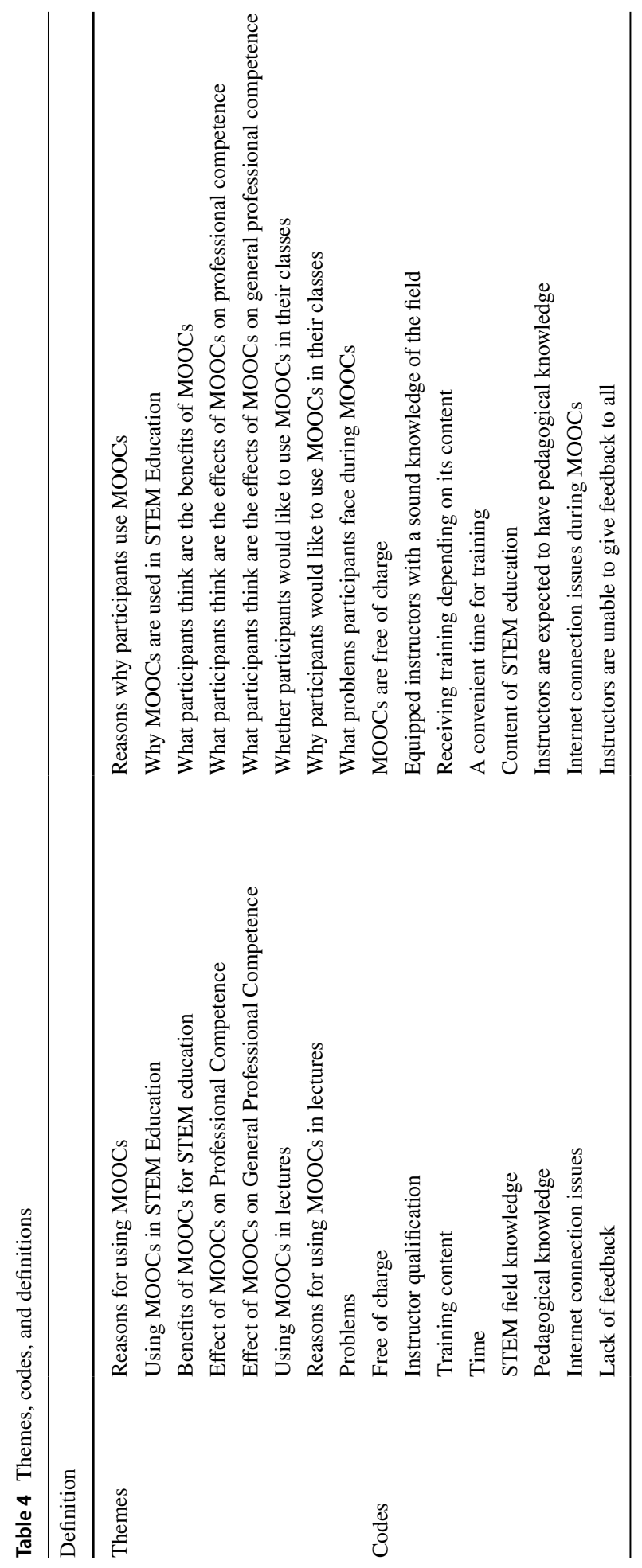


interpreting data, and (8) writing the study. Detailed information about STEM education is below.

\subsection{STEM-PDT-MOOCs Process}

STEM-PDT-MOOCs consisted of two stages. In the first stage, STEM-PDT-MOOCs were designed. In the second stage, teachers were trained. The following is detailed information on the designing process of STEM-PDT-MOOCs.

1. Determining the objective: Objectives of STEM-PDT-MOOCs were determined, which were raising teachers' awareness of MOOCs and ensuring that they learn the program content and pedagogy appropriate for STEM education.

2. Choosing a platform for training: The distance education system of the university was used for STEM-PDT-MOOCs.

3. Determining the duration of STEM-PDT-MOOCs: A teacher needs at least $80 \mathrm{~h}$ of training to achieve professional development (Johnson and Fargo 2010; Supovitz and Turner 2000). Hodges et al. (2016) argue that MOOCs should be long-term so that they can provide teachers with a sustainable learning opportunity. Polly and Hannafin (2010) also state that long-term training promotes teachers' professional development. Therefore, an 80-h training was designed.

4. Determining the format of MOOCs for STEM-PDT-MOOCs: The format was based on xMOOCSs, which, unlike conventional online learning, allows teachers to learn directly.

5. Creating STEM-PDT-MOOCs content: It was made sure that MOOCs addressed different components, such as course introduction and course registration videos, live classes, discussion forums, assignments, and assessment activities (Agarwal 2012; Chamberlin and Parish 2011; Evans 2012). Afterward, STEM education content was determined because it is stated that education content for teachers should focus on a field and offer pedagogy specific to it (Polly et al. 2010). Therefore, specific content was developed. Table 5 provides information on STEM-PDT-MOOCs components and content.

6. Registration: Participants who applied for STEM-PDT-MOOCs were enrolled.

7. Course attendance system: It included course attendance during STEM-PDT-MOOCs. The system sent reminders to those who did not attend classes.

8. Course completion and evaluation: MOOCs were evaluated, and courses were completed.

\subsection{Results}

The results are presented as themes, codes, and quotations to allow readers to analyze and interpret them easily. 


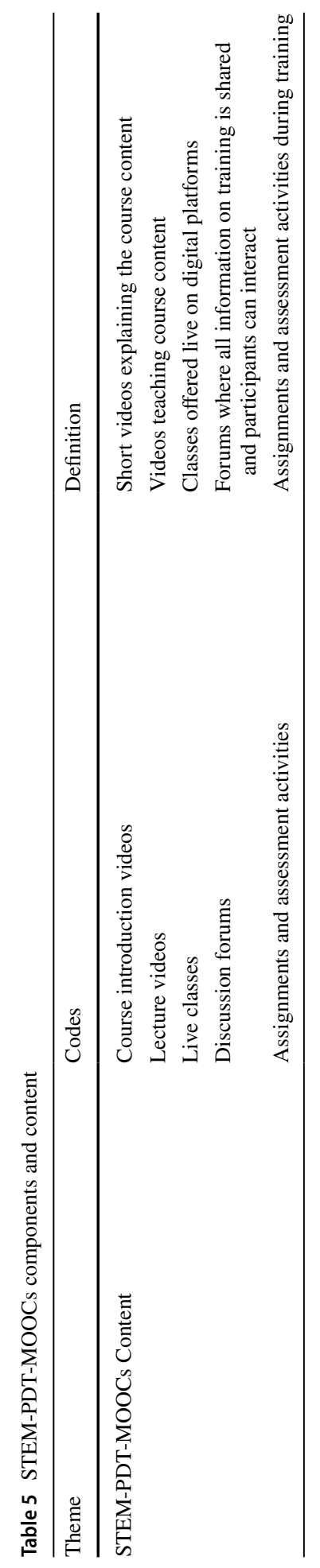




\subsection{Participants' Definitions of MOOCs}

The first subquestion focused on participants' definitions of MOOCs. Table 6 shows the results.

Participants' definitions of MOOCs were grouped under six codes. They mostly defined them as either online courses with different components or as an online version of undergraduate education.

\subsection{Participants' Views of Use of MOOCs for STEM education}

The second subquestion addressed why participants used MOOCs for STEM education. Table 7 shows the results.

\subsection{Participants' Views of Benefits of MOOCs}

The third subquestion addressed participants' views of the benefits of MOOCs for STEM education. Table 8 shows the results.

Participants who found MOOCs useful in STEM education were asked what kind of benefits they thought MOOCs had. Table 9 shows the results.

\subsection{Participants' Views of Effect of MOOCs on Professional Competence}

The fourth subquestion addressed participants' views on the effect of MOOCs on professional competence. Table 10 shows the results.

Most participants stated that MOOCs helped them develop professional competence, while only two stated that MOOCs did not affect it.

Participants who found MOOCs useful were asked in what way MOOCs helped them develop professional competence. Table 11 shows the results.

Participants stated that MOOCs helped them develop general competence in many respects. Their views were grouped under three subcategories; "professional knowledge," "professional skills," and "attitudes and values." They noted that MOOCs taught them about STEM fields, pedagogy, and course planning, and encouraged them to inquire.

\subsection{Participants' Views of Integrating MOOCs into Lectures}

The fifth subquestion addressed participants' views of integrating MOOCs into their classes. Table 12 shows the results.

Participants who were interested in using MOOCs in their classes were asked why they were so. Table 13 shows the results.

Participants who were not interested in using MOOCs in their classes were asked why that was the case. Table 14 shows the results. 


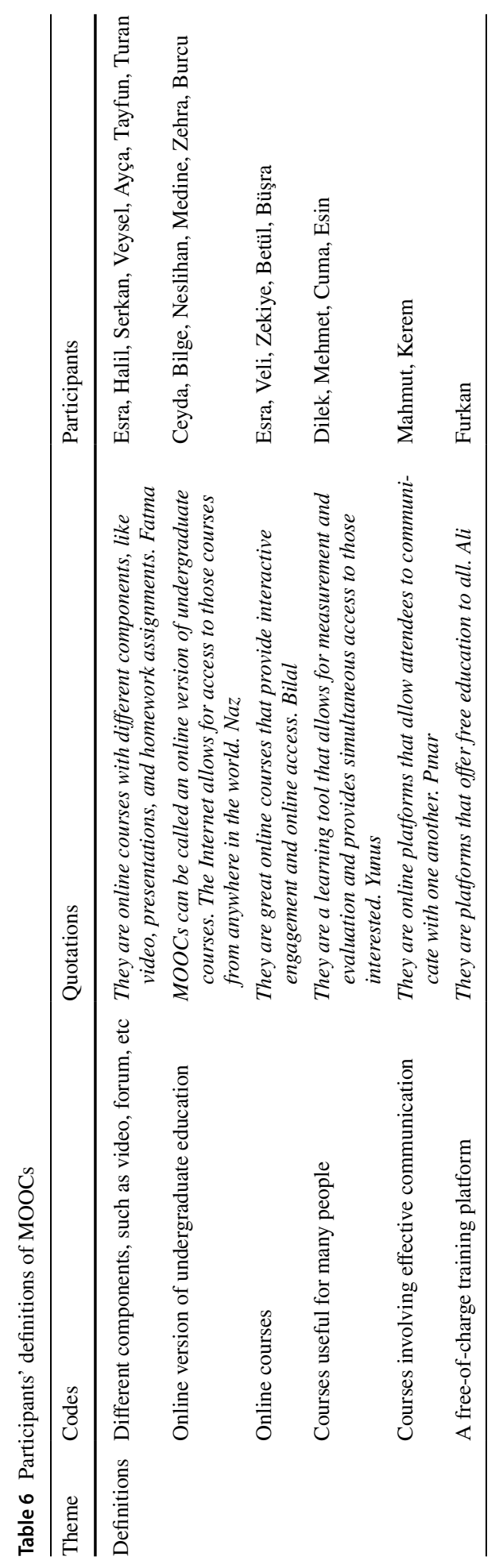




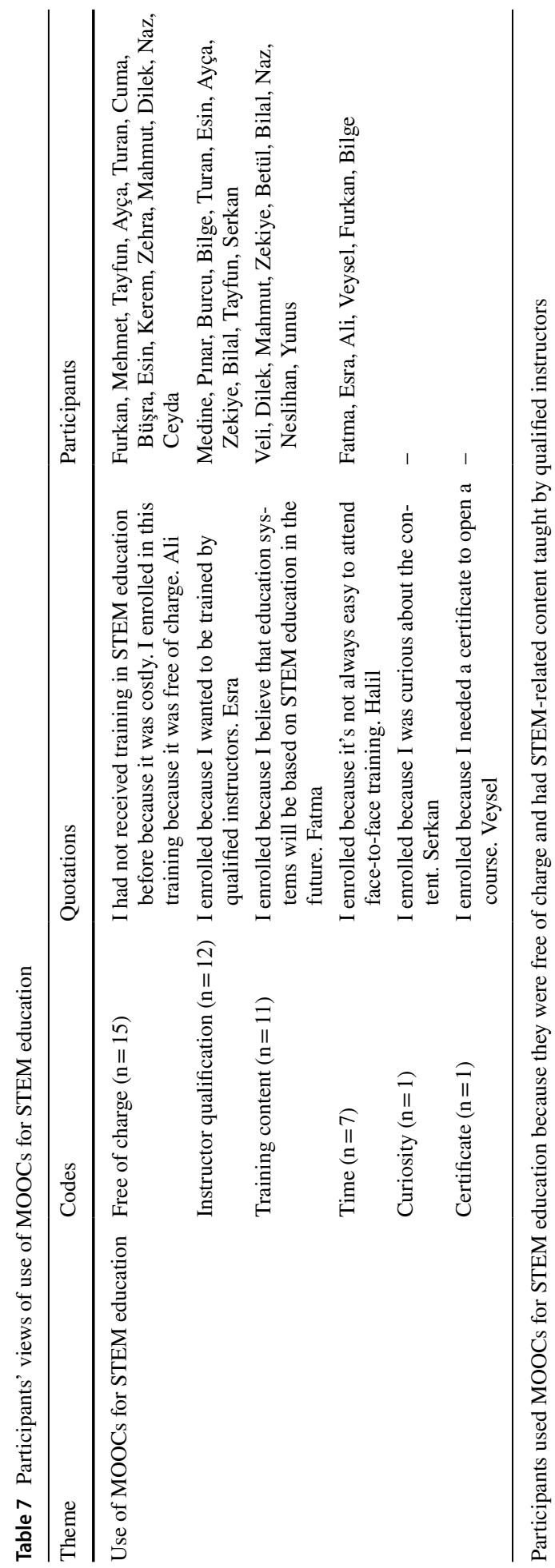




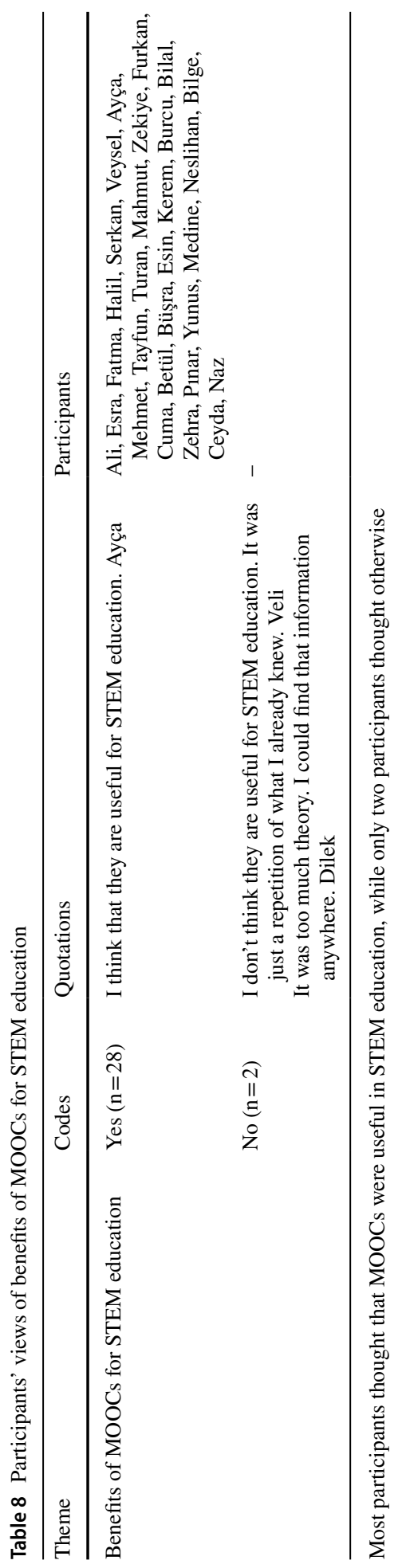




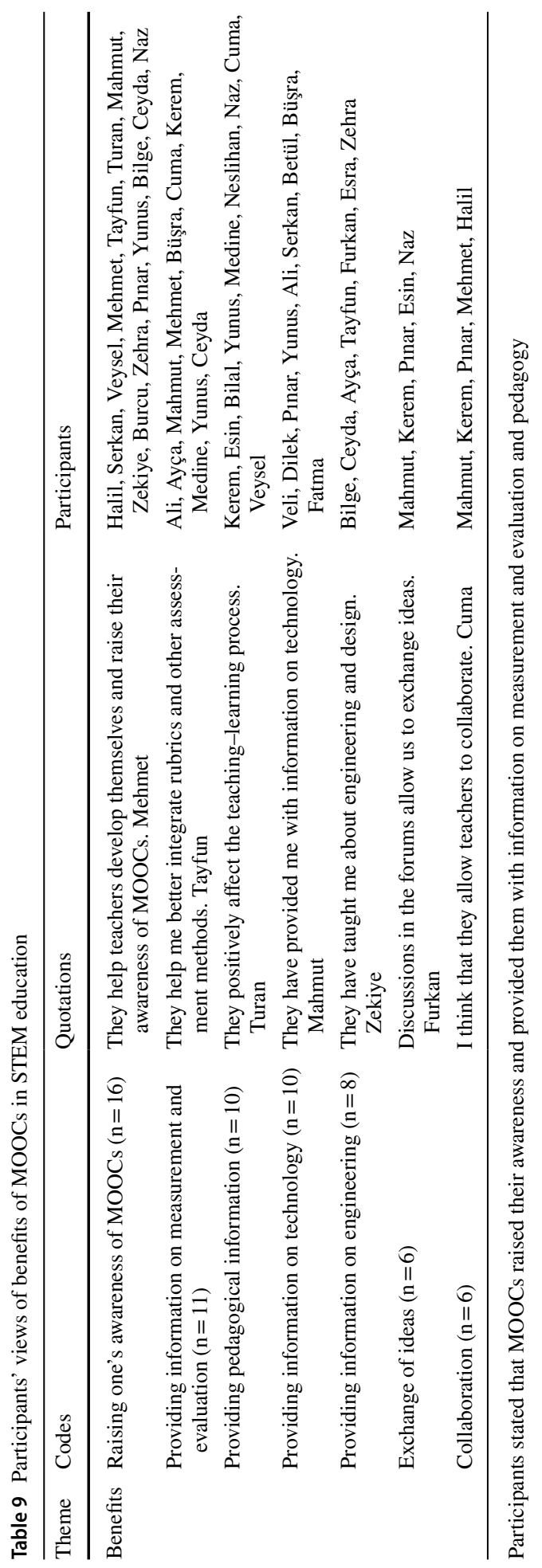




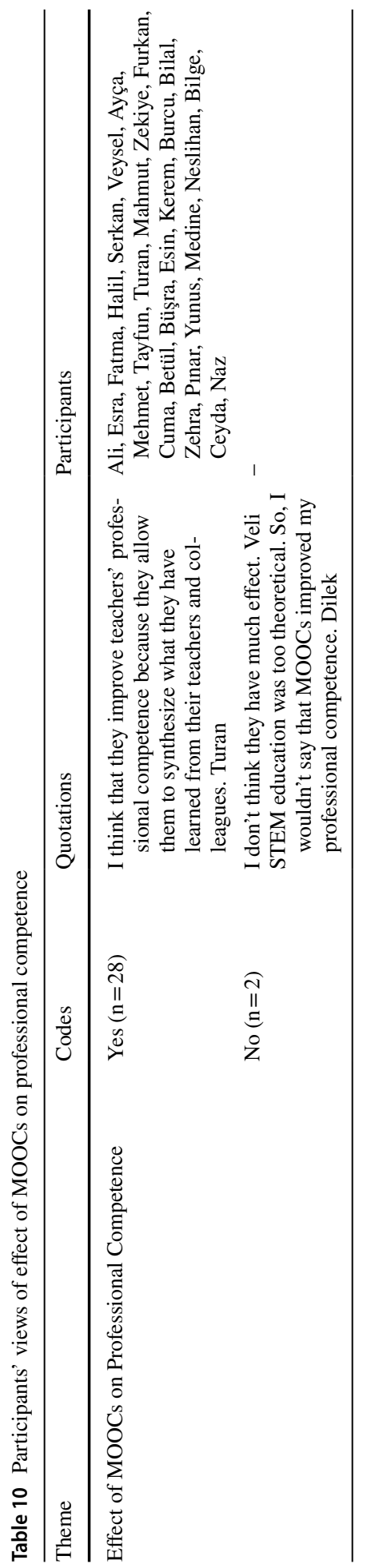




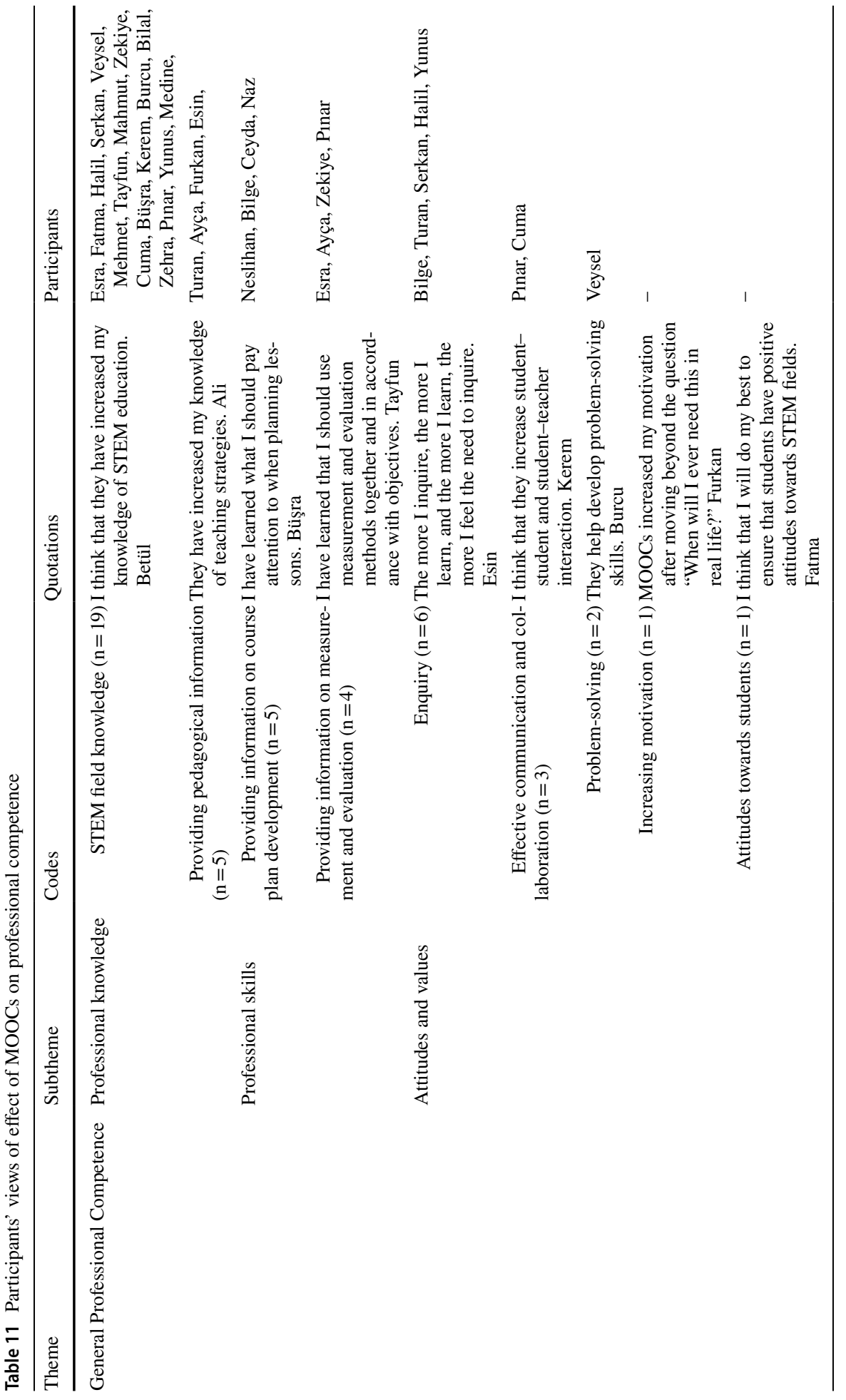




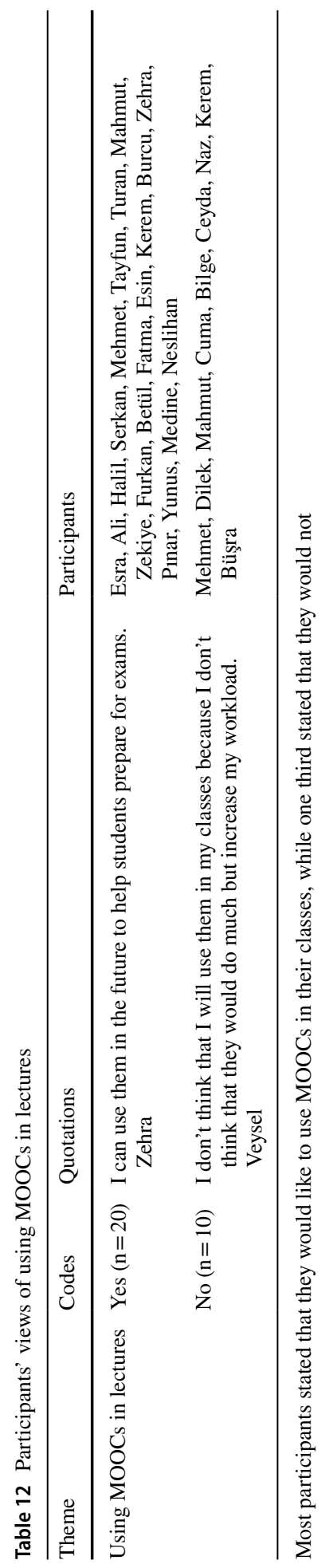




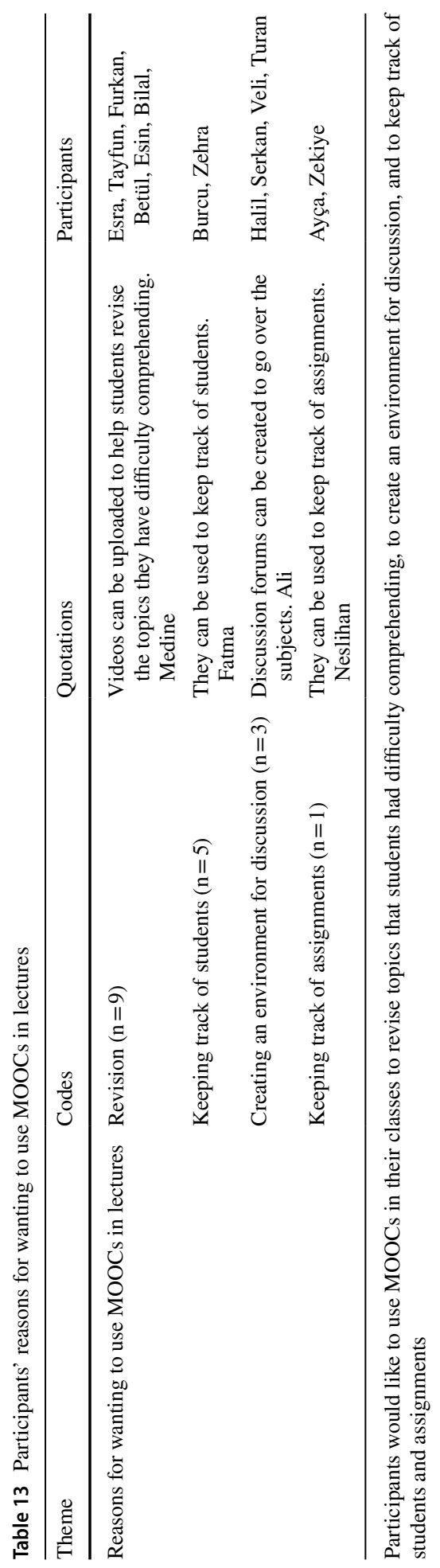




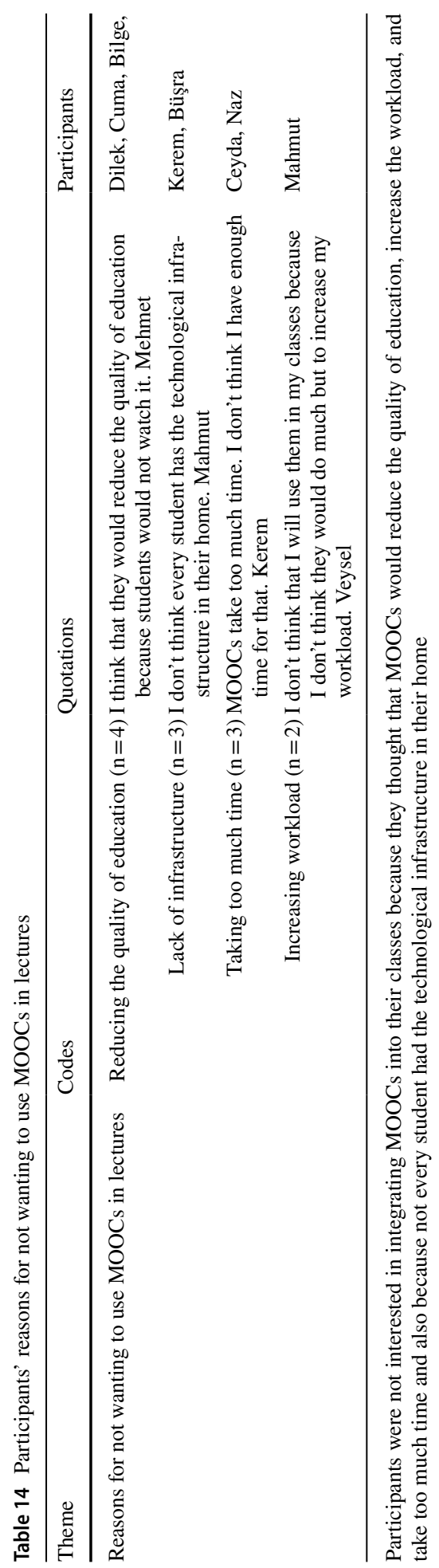




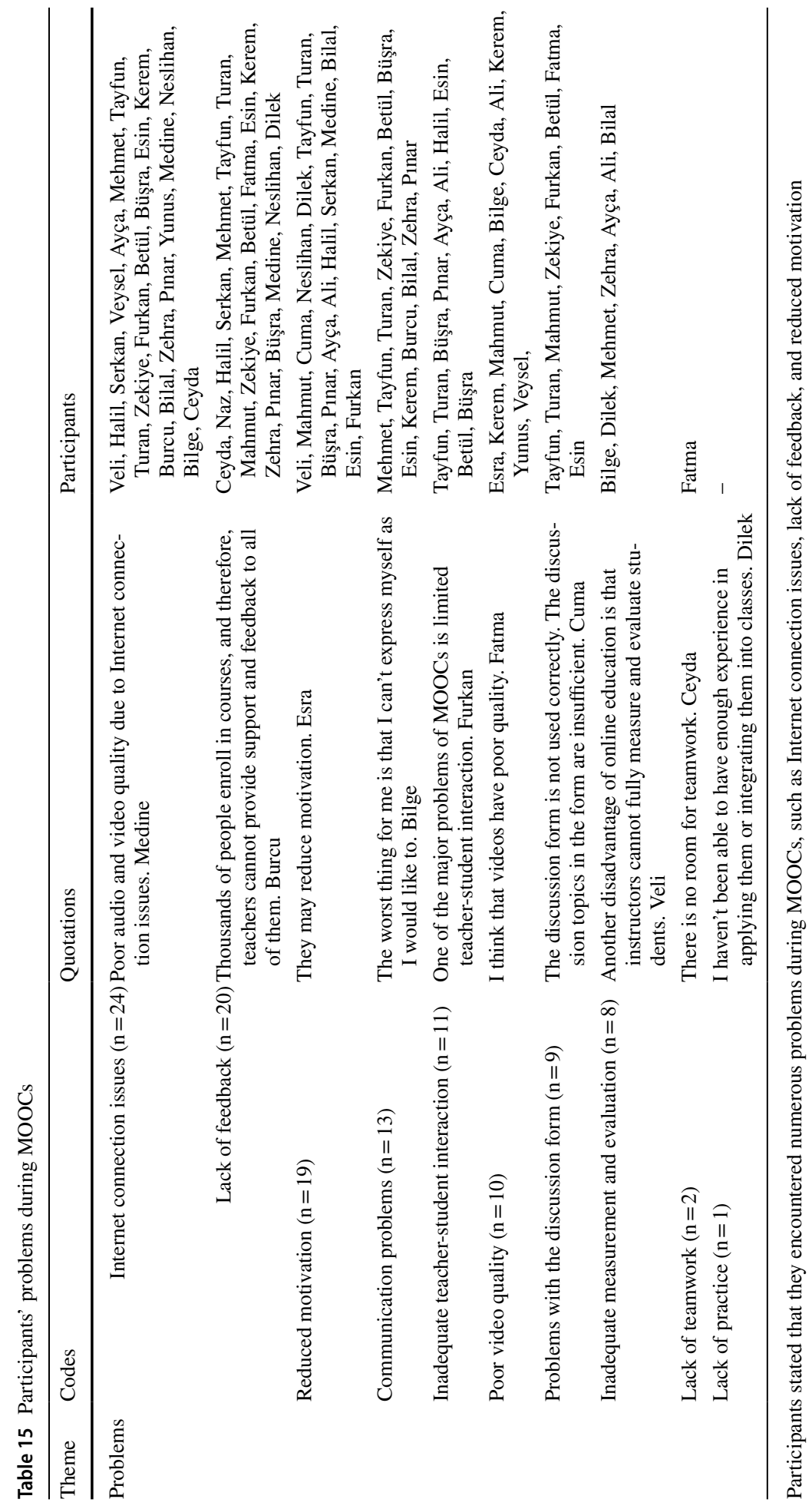




\subsection{Participants' Problems during MOOCs}

The sixth subquestion addressed the problems participants faced during MOOCs. Table 15 shows the results.

\section{Discussion and Conclusion}

This study investigated teachers' views of MOOCs for STEM education and reached the following results:

The first subquestion addressed participants' definitions of MOOCs. They define MOOCs as free-access online educational platforms consisting of videos and forums. This result shows that they understand what a MOOC is because their definitions of MOOCs are similar to those in the literature. For example, Misra (2018) defines MOOCs as an open educational program. Nortvig and Christiansen (2017) define them as an online and free educational platform that is available for anyone to enroll. Margaryan et al. (2015) define them as a new version of online learning.

The second subquestion addressed why participants use MOOCs for STEM education. They use MOOCs because they are flexible, certified, and free of charge courses with STEM-related content taught by qualified instructors. Kirschner (2012) and Martin (2012) also reported that attendees use MOOCs because they would like to learn about a specific field and receive a certificate at the end of training for free. Young (2013) emphasized that one of the main reasons why learners use MOOCs is because they receive a certificate at the end of the training. According to Bali (2013), teachers use MOOCs because they have the opportunity to observe online learning environments, participate in discussions, experience student specializations, and have access to free resources of high quality. Brooks and Gibson (2012) also reported that teachers use MOOCs because those courses are flexible, facilitate teacher-teacher communication, and can be attended anywhere, anytime. These results show that teachers use online education services when they are provided with appropriate learning platforms. The fact that our participants highlighted the content of MOOCs and the qualification of instructors shows that they want to get the right information.

The third subquestion addressed participants' views of the benefits of MOOCs in STEM education. Most participants find MOOCs useful in STEM education, which is consistent with the literature. Subbian (2013) states that MOOCs can be used to facilitate interdisciplinary education, to achieve learning in STEM fields, and to teach the pedagogy of STEM education. Both our results and those of others show that MOOCs can be used in STEM education. Some studies suggest that MOOCs can also be used to teach topics related to specific fields. For example, Parson et al. (2019) reported that most teachers find MOOCs useful for professional development, which is in line with our results. However, some studies argue that MOOCs are not useful (Martin 2012; Miller 2012; Sukhbaatar et al. 2018), which is in contrast to our result. These results show that MOOCs are a new online educational platform that warrants further research. The COVID-19 pandemic has also shown how crucial online education is. MOOCs play a vital role in sustaining education during outbreaks and other extraordinary circumstances. In other words, they are a useful source of training and education for both educators and learners. Moreover, they are convenient because they are easily accessible to anyone interested in deepening their knowledge 
whenever and wherever they want. Therefore, they allow people to access education 24/7 and support lifelong learning. The results show that they can be used to continue education in both ordinary and extraordinary situations, like the COVID-19 pandemic.

Participants think that MOOCs provide information on pedagogy, technology, and engineering. Donitsa-Schmidt and Beverley Topaz (2018) also state that MOOCs provide field knowledge, pedagogical knowledge, and pedagogical field knowledge. Our participants believe that MOOCs also improve communication and collaboration, which is consistent with the literature (Al-Rahmi et al. 2019; Sharov et al. 2019; Skiba 2012; Yuan and Powell 2013). This is a significant result because the exchange of ideas and collaboration is essential for the professional development of teachers (Jho et al. 2016; Jones and Carter 2007).

The fourth subquestion addressed the effect of MOOCs on professional competence. The results show that MOOCs help teachers develop professional competence. Koutsodimou and Jimoyiannis (2015) and Misra (2018) also argue that MOOCs can be used as an alternative for the professional development of teachers because they help teachers develop Web 2.0 knowledge and professional skills. Overall, MOOCs can also be an alternative to in-service training.

Another result of the fourth subquestion is that participants think that MOOCs improve professional knowledge, professional skills, and attitudes and values in various ways. They believe that MOOCs teach them about STEM fields, pedagogy, course planning, and communication, and collaboration. Donitsa-Schmidt and Beverley Topaz (2018) and Urrutia et al. (2016) also note that MOOCs help teachers develop professional, technological, and academic skills. MOOCs are useful in teaching subject-specific topics as well (Karlsson et al. 2014; Koukis and Jimoyiannis 2017; Koutsodimou and Jimoyiannis 2015; Spradling et al. 2015). Our results are consistent with the literature, indicating that well-planned MOOCs can help teachers develop professional competence.

The fifth subquestion addressed participants' views of using MOOCs in lectures. Most participants are interested in using MOOCs in their classes to revise difficult topics, to keep track of students and their assignments, and to create a safe environment for discussion. This result has been reported by Koutsodimou and Jimoyiannis (2015) and Bruff et al. (2013) as well. This result indicates that teachers are open to improving themselves and learning about new approaches. However, some participants are not interested in using MOOCs in their classes because they think that MOOCs reduce the quality of education and increase the workload and also because not every student has the technological infrastructure in their home. This result has been reported by some studies as well (Lederman 2013; Sukhbaatar et al. 2018). This result indicates that those participants are not interested in improving themselves and learning about new approaches.

The sixth subquestion addressed the problems that participants faced during MOOCs. Participants have to deal with Internet connection issues, communication problems, problems with the discussion form, weak student-teacher interaction, poor video quality, inadequate measurement and evaluation, and lack of practice. Moreover, one of the most critical problems of MOOCs is the lack of feedback, according to most participants. However, it is impossible to give feedback to everyone on time due to the nature of MOOCs (Hodges et al. 2016; Roth 2013), which is why student-student interaction is so crucial in MOOCs. These results are similar to ours, suggesting that giving instant feedback to attendees during MOOCs ensures success. Our participants also stated that the lack of feedback during MOOCs reduced their motivation.

Participants lose motivation during MOOCs, making it all the more difficult for them to concentrate on classes. Research also shows that motivation plays a key role in completing MOOCs (Alraimi et al. 2015; Barba et al. 2016). Learners face some other problems 
during MOOCs, such as low teacher-student interaction, a lack of an open environment for discussion, and insufficient infrastructure (Ji and Cao 2016; Karlsson et al. 2014; King et al. 2018; Rice 2013; Christensen and Alcorn 2014). Insufficient infrastructure, reduced motivation, and the lack of feedback are the major obstacles to MOOCs because the completion rate for the most MOOCs is moderate.

\section{Recommendations}

MOOCs help teachers develop professional competence. In case of an excessive number of teachers and inadequate in-service training, MOOCs can be used as an alternative to professional development programs and in-service training. Online learning has become necessary during the COVID-19 pandemic because school closures worldwide have left millions of students out of school. MOOCs ensure that education continues regardless of the circumstances. Therefore, teachers can use them both to receive STEM education and to improve themselves in other fields. For example, Coursera offers online courses for anyone interested in engineering. In this context, MOOCs provide teachers with the opportunity to improve professional competence and ensure lifelong learning.

Our results show that there should also be MOOCs designed for teachers who are interested in improving themselves but want to do it where they are. Such MOOCs can meet teachers' learning needs and promote personal development.

The problems that teachers face should be taken into account when designing MOOCs. For example, the completion rate for MOOCs is moderate due to the loss of motivation and the lack of feedback. Therefore, MOOCs should be designed in such a way that they can increase participants' motivation and allow for feedback.

Some participants are interested in using MOOCs in their classes while some others are not. Teachers' views should be taken into consideration, and classes should integrate MOOCs with face-to-face learning. We believe that this type of teaching can improve the quality of education and encourage learners to engage more in learning. Further research should address the effects of MOOCs combined with face-to-face learning.

This study shows that MOOCs should be used in STEM education. Further research should be conducted to better understand the effects of MOOCs on teacher training and to identify its challenges in order to design the best learning experiences.

\section{Limitations}

The study had three limitations. First, the sample consisted only of Turkish teachers who were interested in STEM education, and therefore, the results cannot be generalized. Second, the sample size was too small to understand the advantages and disadvantages of MOOCs for teacher training better. Third, phenomenology was the method of choice for capturing teachers' experience with MOOCs. However, phenomenology may fall short of obtaining in-depth and detailed information on the phenomenon in question.

\section{Compliance with Ethical Standards}

Conflict of interest The author declare that they have no conflict of interest. 


\section{Appendix}

\section{FSEMOOCs}

1. How do you define MOOCs?

2. Why do you use MOOCs?

3. What do you think about using MOOCs for STEM education?

4. What do you think are the benefits of MOOCs for STEM education?

5. Do you think that MOOCs help to improve professional competence?

6. In what way do you think MOOCs help to improve professional competence?

7. What do you think about integrating MOOCs into classes?

8. What problems do you face during MOOCs?

\section{References}

Al-Rahmi, W., Aldraiweesh, A., Yahaya, N., Kamin, Y. B., \& Zeki, A. M. (2019). Massive open online courses (MOOCs): Data on higher education. Computers and Education, 22(2019), 118-125. https:// doi.org/10.1016/j.dib.2018.11.139

Alraimi, K. M., Zo, H., \& Ciganek, A. P. (2015). Understanding the MOOCs continuance: The role of openness and reputation. Computers and Education, 80(2015), 28-38.

Agarwal, A. (2012). Circuits and electronics: MITx. Chronicle of Higher Education, 59(6), B10.

Baggaley, J. (2013). MOOC rampant. Distance Education, 34(3), 368-378. https://doi.org/10.1080/01587 919.2013 .835768

Bali, M. (2013, July). 5 reasons teachers should dip into MOOCs for professional development. MOOC news and reviews. Retrieved from https://moocnewsandreviews.com/5-reasons-teachersshould-dipinto-moocs-for-professional-development-2/

Barba, P. D., Kennedy, G. E., \& Ainley, M. D. (2016). The role of students' motivation and participation in predicting performance in a MOOC motivation and participation in MOOCs. Journal of Computer Assisted Learning, 32, 218-231.

Bellack, J. P. (2013). MOOCs: The future is here. Journal of Nursing Education, 52(1), 3-4. https://doi. org/10.3928/01484834-20121227-10

Bozna, H. (2016). Lisansüstü Türk öğrencilerin kitlesel açık çevrimiçi dersleri (MOOC) bırakma konularındaki alglları [perceptions of Turkish graduate students of dropping mass open online courses (MOOC)]. Açık̈̈̆rretim Uygulamaları ve Araştırmaları Dergisi, 2(2), 72-88.

Brooks, C., \& Gibson, S. (2012). Professional learning in a digital age. Canadian Journal of Learning and Technology, 38(2), 1-17.

Bruff, D. O., Fisher, D. H., McEwen, K. E., \& Smith, B. E. (2013). Wrapping a MOOC: Student perceptions of an experiment in blended learning. MERLOT Journal of Online Learning and Teaching, 9(2). Retrieved from https://jolt.merlot.org/vol9no2/bruff_0613.htm

Castaño-Muñoz, J., Kalz, M., Kreijns, K., \& Punie, Y. (2018). Who is taking MOOCs for teachers' professional development on the use of ICT? A crosssectional study from Spain. Technology, Pedagogy and Education, 27(5), 607-624. https://doi.org/10.1080/1475939X.2018.1528997

Chamberlin, L., \& Parish, T. (2011). MOOCs: Massive open online courses or massive and often obtuse courses? eLearn Magazine. Retrieved from https://elearnmag.acm.org/featured.cfm?aid=2016017

Christensen, G., \& Alcorn, B. (2014). Are free online university courses an educational panacea? New Scientist, 221(2959), 24-25. https://doi.org/10.1016/S0262-4079(14)60484-X

Colakoglu, M. H., \& Gokben, A. G. (2017). STEM studies in Turkish faculties of education. Journal of Research in Informal Environments (JRINEN), 2(2), 46-69.

Conole, G. (2014). A new classification schema for MOOCs. International Journal for Innovation and Quality in Learning, 2(3), 65-77. 
Conole, G. (2013). MOOCs as disruptive technologies: Strategies for enhancing the learner experience and quality of MOOCs. Revista de Educación a Distancia., 39, 1-17.

Cormier, D., \& Siemens, G. (2010). Through the open door: Open courses as research, learning, and engagement. EDUCAUSE Review, 45(4), 30-39.

Daniel, J. (2012). Making sense of MOOCs: Musings in a maze of myth, paradox and possibility. Journal of Interactive Media in Education, 3. Retrieved from https://wwwjime.open.ac.uk/jime/article/viewArticl $\mathrm{e} / 2012-18 / \mathrm{html}$

Donitsa-Schmidt, S., \& Topaz, B. (2018). Massive open online courses as a knowledge base for teachers. Journal of Education for Teaching, 44(5), 608-620. https://doi.org/10.1080/02607476.2018.1516350

Downes S., \& Siemens, G. (2008). Connectivism and connected knowledge. Retrieved from: http://ltc. umanitoba.ca/connectivism/.

Evans, D. (2012). Introduction to computer science: Udacity. Chronicle of Higher Education, 59(6), B11.

Hodges, C., Lowenthal, P., \& Grant, M. (2016). Teacher professional development in the digital age: Design considerations for MOOCs for teachers. In Proceedings of Society for Information Technology \& Teacher Education International Conference (pp. 2075-2081). Chesapeake, VA: Association for the Advancement of Computing in Education (AACE).

Ji, Z., \& Cao, Y. (2016). Prospective study on the application of MOOC in teacher professional development in china. Universal Journal of Educational Research, 4(9), 2061-2067. https://doi.org/10.13189/ ujer.2016.040917

Jho, H., Hong, O., \& Song, J. (2016). An analysis of STEM/STEAM teacher education in Korea with a case study of two schools from a community of practice perspective. Eurasia Journal of Mathematics, Science and Technology Education, 12(7), 1843-1862. https://doi.org/10.12973/eurasia.2016.1538a

Jones, M. G., \& Carter, G. (2007). Science teacher attitudes and beliefs. In S. K. Abell \& N. G. Lederman (Eds.), Handbook of research on science education (pp. 1067-1104). Mahwah, NJ: Lawrence Erlbaum Associates.

Johnson, C. C., \& Fargo, J. D. (2010). Urban school reform enabled by transformative professional development: Impact on teacher change and student learning of science. Urban Education, 45(1), 4-29. https:// doi.org/10.1177/0042085909352073.

Jordan, K. (2014). Initial trends in enrolment and completion of massive open online courses. The International Review of Research in Open and Distributed Learning, 15(1), 133-160. https://doi.org/10.19173/ irrodl.v15i1.1651

Türk, N., Kalaycı, N., \& Yamak, H. (2018). New trends in hinger education the globalizing World: STEM in teacher education. Universal Journal of Educational Research, 6(6), 1286-1304. https://doi.org/10.13189 /ujer.2018.060620

Karlsson, N., Godhe, A., Bradley, L., \& Lindström, B. (2014). Professional development of teachers in a MOOC. Proceedings of the 22nd international conference on computers in education. Asia- Pacific Society for Computers in Education, Japan, pp. 868-877. Retrieved from https://pellepedagog.se/wp-content/ uploads/2015/01/Professional-Development-of-Teachers-in-a-MOOC.pdf

Kellogg, S., \& Edelmann, A. (2015). Massively open online course for educators (MOOC-Ed) networkdataset. British Journal of Educational Technology, 46(5), 977-983.

King, M., Pegrum, M., \& Forsey, M. (2018). MOOCs and OER in the global south: Problems and potential. The International Review of Research in Open and Distributed Learning. https://doi.org/10.19173/irrodl.v19i5 .3742

Kirschner, A. (2012). A pioneer in online education tries a MOOC. Chronicle of Higher Education, 59(6), B21-22.

Koukis, N., \& Jimoyiannis, A. (2017). Designing MOOCs for teacher professional development: Analysis of participants' engagement. Proceedings of the 16th European Conference on eLearning, ECEL 2017, ACPI, Porto, pp. 271-280.

Koukis, N., \& Jimoyiannis, A. (2018). MOOCs and teacher professional development: A Case study on teachers' views and perceptions. In M. Baptista \& P. Isaías (Eds.), MCCSIS 2018 Multi Conference on Computer Science and Information Systems. Proceedings of the International Conference E-Learning 2018 (pp. 19-26). Madrid: IADIS Press.

Koutsodimou, K., \& Jimoyiannis, A. (2015). MOOCs for teacher professional development: investigating views and perceptions of the participants. Proceedings of the 8th international conference of education, research and innovation - ICERI2015, IATED, Seville, Spain. pp. 6968-6977.

Laurillard, D. (2016). The educational problem that MOOCs could solve: Professional development for teachers of disadvantaged students. Research in Learning Technology, 24, 1-17. https://doi.org/10.3402/rlt. v24.29369 
Lederman, D. (2013). Expanding pathways to MOOC credit. Inside higher education. Retrieved from http:// www.insidehighered.com/news/2013/02/07/ace-deems-5-massive-open-courses-worthy-credit.

Margaryan, A., Bianco, M., \& Littlejohn, A. (2015). Instructional quality of massive open online courses (MOOCs). Computers \& Education, 80(2015), 77-83. https://doi.org/10.1016/j.compedu.2014.08.005

Martin, N. (2012). MOOCs are massive. Training and Development, 39(5), 32-33.

Miller, T. (2012). MOOCs break down barriers to knowledge, higher education. Retrieved from https://www. theaustralian.com.au/higher-education/opinion/moocs-break-dow

Misra, P. K. (2018). MOOCs for Teacher professional development: Reflections and suggested actions. Open Praxis, 10(1), 67-77.

Merriam, S. B. (2009). Qualitative research. A guide to design and implementation (2th ed.). San Francisco, CA: Jossey-Bass.

Nortvig, A. M., \& Christiansen, R. B. (2017). Institutional collaboration on MOOCs in education-a literature review. The International Review of Research in Open and Distributed Learning. https://doi.org/10.19173 /irrodl.v18i6.3110

Parsons, S. A., Hutchison, A. C., Hall, L. A., Parsons, A. W., Ives, S. T., \& Leggett, A. B. (2019). U.S. teachers' perceptions of online professional development. Teaching and Teacher Education, 82(1), 33-42. https:// doi.org/10.1016/j.tate.2019.03.006

Polly, D., \& Hannafin, M. J. (2010). Reexamining technology's role in learner-centered professional development. Educational Technology Research and Development, 58(5), 557-571.

Polly, D., Mims, C., Shepherd, C. E., \& Inan, F. (2010). Evidence of impact: An analysis of the influence of PT3 Projects designed to transform methods courses and field experiences. Teaching and Teacher Education, 26(4), 863-870.

Radoiu, D. (2014). Organization and constraints of a recommender system for MOOCs. Scientific Bulletin of the Petru Maio University of Tirgu Mures, 11, 55-59.

Rice, J. (2013). What I learned in MOOC. College Composition and Communication, 64(4), 695-703.

Roth, M. S. (2013). My modern experience teaching a MOOC. Chronicle of Higher Education, 59(34), B18-21.

Patton, M. (2002). Qualitative evaluation and research methods. Beverly Hills, CA: SAGE.

Sahin, A. (Ed.). (2015). A practice-based model of STEM teaching: STEM students on the stage (SOS). Rotterdam: Sense Publishers.

Sharma, N., Doherty, I., \& Harbutt, D. (2014). MOOCs and SMOCs: Changing the face of medical education? Perspectives on Medical Education, 3, 508-509. https://doi.org/10.1007/s40037-013-0103-y

Sharov, S., Liapunova, V., \& Sharova, T. (2019). Analysis of the opportunities of the prometheus platform for the professional development of future teachers. TEM Journal, 8(4), 1469-1476. https://doi.org/10.18421 /TEM84-52

Skiba, D. J. (2012). Disruption in higher education: Massively open online courses (MOOCs). Nursing education perspectives, 33(6), 416-418. https://doi.org/10.5480/1536-5026-33.6.416

Spradling, C., Linville, D., Rogers, M. P., \& Clark, J. (2015). Are MOOCs an appropriate pedagogy for training K-12 teachers computer science concepts? Journal of Computing Sciences in Colleges, 30(5), 115-125.

Subbian, V. (2013). Role of MOOCs in integrated STEM education: a learning perspective. 2013 IEEE Integrated STEM Education Conference (ISEC). Princeton, NJ: IEEE. https://doi.org/10.1109/ISECo n.2013.6525230.

Supovitz, J. A., \& Turner, H. M. (2000). The effects of professional development on science teaching practices and classroom culture. Journal of Research in Science Teaching, 37(9), 963-980.

Sukhbaatar, O., Choimaa, L., \& Usagawa, T. (2018). Students' perception and experience of massive open online courses in Mongolia. Creative Education, 9, 1818-1828. https://doi.org/10.4236/ce.2018.912132

Turan, Z., Küçük, S., \& Gündoğdu, K. (2013). Use of information technology in teacher education: Current and expected status. Journal of Educational Sciences, 4(1), 1-9.

U.S. Department of Education, (2015). STEM 2026: A Vision for innovation in STEM education. Retrieved from https://www.air.org/system/files/downloads/report/STEM-2026-Vision-for-Innovation-September2016.pdf

Urrutia, M. L., Fielding, S., \& White, S. (2016). Professional development through MOOCs in higher education institutions: Challenges and opportunities for $\mathrm{PhD}$ students working as mentors. Journal of Interactive Media in Education, 1, 1-10.

Vivian, R., Falkner, K., \& Falkner, N. (2014). Addressing the challenges of a new digital technologies curriculum: MOOCs as a scalable solution for teacher professional development. Research in Learning Technology, 22, 1-19. https://doi.org/10.3402/rlt.v22.24691

Wang, Q., Chen, B., Fan, Y., \& Zhang, G. (2018). MOOCs as an alternative for teacher professional development: Examining learner persistence in one chinese MOOC. Peking University. , Beijing. Retrieved from https://dl4d.org/wp-content/uploads/2018/05/China-MOOC.pdf 
Yıldırım, A., \& Şimşek, H. (2011). Sosyal bilimlerde nitel araştırma yöntemleri [qualitative research methods in social sciences]. Ankara: Seçkin.

Yıldırım, B. (2020a). Preschool STEM activities: Preschool teachers' preparation and views. Early Childhood Education Journal. https://doi.org/10.1007/s10643-020-01056-2

Yildırım, B. (2020b). A model proposal for teacher training: STEM teacher institutes training model. Pamukkale Üniversitesi Ĕ̆itim Fakültesi Dergisi. https://doi.org/10.9779/pauefd.586603

Yıldırım, B., \& Şahin-Topalcengiz, E. (2019). STEM pedagogical content knowledge scale (STEMPCK): A validity and reliability study. Journal of STEM Teacher Education. https://doi.org/10.30707/JSTE53.2Yild irim

Yuan, L., \& Powell, P. (2013). MOOCs and open education: Implications for higher education. eLearning Papers, 33(2), 1-7.

Young, J. R. (2013). What professors can learn from 'hard core' MOOC students. Chronicle of Higher Education, 59(37), A4.

Publisher's Note Springer Nature remains neutral with regard to jurisdictional claims in published maps and institutional affiliations. 